\title{
ЗАГАЛЬНІ ПІДХОДИ ТА ОСОБЛИВОСТІ \\ НОРМАТИВНО-ПРАВОВОГО РЕГУЛЮВАННЯ МІЖНАРОДНОЇ \\ ТОРГІВЛІ СІЛЬСЬКОГОСПОДАРСЬКИМИ ТОВАРАМИ МІЖ ЄВРОПЕЙСЬКИМ СОЮЗОМ І УКРАЇНОЮ
}

Голубєва В. О.

\section{ВСТУП}

Поглиблення процесів глобалізації та лібералізації світової торгівлі впливає на всі сегменти світового ринку, на світовий ринок сільськогосподарської продукції також. Правове регулювання міжнародної торгівлі сільськогосподарською продукцією набуває особливого значення в контексті:

- прагнення кожної країни знайти баланс між якомога повнішою інтеграцією до світового торговельного простору та захистом національних інтересів;

- розвитку регіональних інтеграційних організацій, що діють у сфері міжнародних сільськогосподарських відносин на основі спільної або скоординованої аграрної політики;

- розширення ринків збуту, захисту національних товаровиробника та товароспоживача за допомогою міжнародних (універсальні, регіональні, національні) механізмів тощо.

Організаційно-правове регулювання стає необхідним елементом управління світовим ринком сільськогосподарської продукції, оскільки воно $\epsilon$ сукупністю методів, що дозволяють реалізувати принципи міжнародної торгівлі, нівелювати диспропорції економічного розвитку країн, сприяти розвитку світового сільського господарства як галузі, що має пріоритетне значення для всіх регіонів і держав світу і відіграє значну роль у гарантуванні світової продовольчої безпеки, економічного та соціального розвитку країн.

Сільськогосподарський сектор найменше пристосований для вільної торгівлі, наприклад, через специфіку кліматичних та природоресурсних особливостей країн. Торгівля сільськогосподарськими товарами завжди була досить чутливою сферою, тому що майже кожна держава має власну сільськогосподарську (аграрну) галузь, яка хоча б мінімально задовольняє потреби країни в продуктах харчування, які в разі нестачі чи перевиробництва експортуються/імпортуються. Також не можна не зазначити, що сільське господарство $є$ складником національної економіки, сферою зайнятості населення, частиною міжнародного поділу праці та 
світової торгівлі. У багатьох державах для підтримки національного виробника сільськогосподарської продукції традиційно застосовувалися різного роду заходи неринкового характеру. Зазвичай держави відгороджували національне виробництво від іноземної конкуренції за допомогою кількісних обмежень, стимулювали рух своєї продукції на іноземні ринки шляхом субсидування тощо. Саме в часи суттєвої глобальної нестачі продуктів харчування і проблеми голоду в багатьох регіонах світу особливо актуальними є питання регулювання міжнародної торгівлі сільськогосподарською продукцією в межах уніфікованих багатосторонніх універсальних (всесвітніх) та регіональних (зокрема, регіональних економічних об'єднань/інтеграцій) систем, крім того, не можна забувати й про національне інституційно-правове забезпечення/регулювання.

Процеси глобалізації та лібералізації спричинили неабиякий вплив на розвиток міжнародної торгівлі: у сучасних умовах торгівля між країнами стала відкритішою, що сприяло активізації руху товарів, капіталів і послуг. 3 огляду на економічні, географічні, історичні, геологічні та соціальні чинники, у кожної країни $\epsilon$ незамінні ресурси та переваги в міжнародному розподілі виробництва, тому держава практично не може розвиватися ізольовано, а лише в співпраці з іншими. За таких обставин багато питань, які раніше були врегульовані національним законодавством, перейшли до сфери міжнародного регулювання, i виникла необхідність у наближенні/гармонізації національного законодавства до міжнародних норм/правил.

Взаємозв'язок між торгівлею, продовольчою безпекою та харчуванням привертає підвищену увагу в контексті порядку денного як у сфері торгівлі, так і у сфері розвитку. Ліквідація голоду на глобальному рівні до 2030 р. є однією із ключових цілей, поставлених у сфері сталого розвитку, а торгівля - один із засобів досягнення цілей сталого розвитку. Очікується, що зі зміною моделей споживання та виробництва світова торгівля сільськогосподарською продукцією в найближчі десятиліття зростатиме, що істотно вплине на масштаб і характер продовольчої безпеки в усіх регіонах світу. Тому нині доцільне розроблення альтернативної торговельної політики, щоби міжнародна торгівля сільськогосподарською продукцією не лише мала комерційний характер, а й працювала на ганатування продовольчої безпеки у світі.

Україна $\epsilon$ одним із найбільших учасників міжнародних сільськогосподарських відносин, членом СОТ, учасницею міжнародних товарних організацій/угод, партнером Європейського Союзу (далі - ЄС). Значно вплинуло на розвиток зовнішньоторговельних відносин щодо сільськогосподарської продукції ухвалення Угоди про асоціацію 3 СС 
2014 p. ${ }^{1}$, відповідно до якої знижені/скасовані в рамках тарифних квот ставки мита на різні види сільськогосподарської продукції (зокрема, зернової та м'ясної - ставка мита 0\%). Тому дослідження в цій галузі сприяють посиленню торгових зв'язків з СС, збільшенню обсягів поставок української сільськогосподарської продукції на його ринок. Аналіз нормативно-правових актів $€ C$, якими регулюється імпорт/експорт сільськогосподарської продукції, дасть змогу визначити сучасні тенденції розвитку організаційно-правового регулювання/забезпечення виробництва і контролю якості сільськогосподарської, зокрема харчової, продукції, проаналізувати механізм інституційно-правового забезпечення здійснення імпортно-експортних операцій в іноземних країнах, а також перейняти досвід реалізації успішних проектів і впроваджувати ці знання на національному рівні.

\section{1. Вплив Угоди про асоціацію між Україною та ЄС 2014 р. на інституційно-правове регулювання сільськогосподарського ринку зони вільної торгівлі}

Питання взаємної торгівлі між Україною та $Є C$ регулюються p. IV «Торгівля і питання, пов'язані з торгівлею» Угоди про асоціацію між Україною та ЄС 2014 p. ${ }^{2}$ (далі - Угода про асоціацію). Часткове застосування Угоди про асоціацію почалося ще 2014 р., але 3 певних причин мало місце відтермінування щодо p. IV, зокрема, графік тимчасового застосування торговельної частини Угоди закріплено в рішенні Ради СС від 29 вересня 2014 р. № 2014/691/ЄC 3 . 1 січня 2016 р. розпочалося тимчасове застосування $\mathrm{p}$. IV Угоди про асоціацію в частині поглибленої та всеохоплюючої зони вільної торгівлі ${ }^{4}$. А 1 вересня 2017 р. Угода про асоціацію набула чинності в повному обсязі ${ }^{5}$, що серйозно впливає на розвиток сільськогосподарської сфери, тому що для українських сільськогосподарських виробників/експортерів відкриваються кращі перспективи виходу на ринок $\mathrm{CC}$, підвищення рівня якості,

\footnotetext{
${ }^{1}$ Про ратифікацію Угоди про асоціацію між Україною, з однієї сторони, та Європейським Союзом, Свропейським співтовариством 3 атомної енергії і їхніми державами-членами, з іншої сторони : Закон України від 16 вересня 2014 р. № 1678-VII. Відомості Верховної Ради Украӥни. 2014. № 40. Ст. 2021.

2 Угода про асоціацію між Україною, $з$ однієї сторони, та Європейським Союзом, Європейським співтовариством з атомної енергії і їхніми державами-членами, з іншої сторони, від 27 червня 2014 р. URL: http://zakon2.rada.gov.ua/laws/show/984_011.

${ }^{3}$ Про внесення змін до Рішення Ради СС № 2014/668/EU від 23 червня 2014 р. стосовно підписання та тимчасове застосування Угоди про асоціацію між Україною та ЄС і його державами-членами : рішення Ради СС від 29 вересня 2014 p. № 2014/691/EU. URL: http://eur-lex.europa.eu/legalcontent/EN/TXT/?uri=CELEX\%3A32014D0691.

${ }^{4}$ Офіційний сайт Представництва України при Європейському Союзі та Європейському Співтоваристві з атомної енергії. URL: https://ukraine-eu.mfa.gov.ua/ua/ukraine-eu/trade-and-economic/atm.

5 Офіційний сайт Міністерства економічного розвитку та торгівлі України. URL: http://www.me.gov.ua/?lang=uk-UA.
} 
безпечності й екологічних характеристик вітчизняної сільськогосподарської продукції, також формується конкурентне середовище на внутрішньому ринку, з'являються регуляторні інструменти у сфері санітарних та фітосанітарних заходів, розширюються можливості для обміну досвідом та технологіями.

Важливим і одним із ключових положень Угоди про асоціацію $\epsilon$ наближення законодавства й адміністративних процедур України до відповідних норм та процедур $\epsilon^{6}$. Найдовший період імплементації в Угоді про асоціацію визначений саме для аграрного сектора - 10 років $^{7}$, варто зазначити, що Україна вже здійснила значні кроки в цьому напрямі.

Відповідно до ст. 56 гл. 3 «Технічні бар'єри у торгівлі», 3 метою усунення нетарифних торговельних бар'єрів Україна повинна наблизити національне законодавство до положень технічних регламентів та систем стандартизації, метрології, акредитації, оцінки відповідності та ринкового нагляду $\mathrm{CC}$. Закон України «Про технічні регламенти та оцінку відповідності» ${ }^{8}$ ухвалено Верховною Радою України 15 січня 2015 р., також на окрему увагу заслуговує розпорядження Кабінету Міністрів України від 19 серпня 2015 р. № 844-р «Про стратегію розвитку системи технічного регулювання на період до 2020 р.» ${ }^{9}$.

Відповідно до ст. 59 Угоди про асоціацію, метою гл. 4 «Санітарні та фітосанітарні заходи» p. IV «Торгівля і питання, пов'язані з торгівлею» $\epsilon$ сприяння торгівлі товарами між Україною та ЄС, що охоплює санітарні та фітосанітарні заходи під час забезпечення охорони здоров'я людей, тварин та рослин, шляхом наближення української нормативно-правової бази до норм Свропейського Союзу. Для імплементації вимог гл. 4 Кабінет Міністрів України своїм розпорядженням № 228-р від 24 лютого 2016 р. схвалив Всеохоплюючу стратегію імплементації гл. 4 Угоди про асоціацію ${ }^{10}$ (далі Стратегія). Наприклад, у р. 2 Стратегії «Здоров’я тварин» зазначено заходи, що застосовуються до основних категорій живих тварин, заходи щодо хвороб

6 Офіційний сайт Представництва України при Європейському Союзі та Європейському Співтоваристві з атомної енергіï. URL: https://ukraine-eu.mfa.gov.ua/ua/ukraine-eu/trade-and-economic/atm.

7 Заблоцький А. Коментар керівника сектора BRDO «Сільське господарство». Протокол круглого столу «Украӥнський ринок зерна: ефективне регулювання для світового лідерства». Київ, 2017. С. 1-7.

8 Про технічні регламенти та оцінку відповідності : Закон України від 15 січня 2015 р. № 124-VIII. URL: https://zakon.rada.gov.ua/laws/show/124-19.

9 Про схвалення Стратегії розвитку системи технічного регулювання на період до 2020 р. : розпорядження Кабінету Міністрів України від 19 серпня 2015 p. № 844-p. URL: http://zakon2.rada.gov.ua/laws/show/844-2015-\%D1\%80\#n7.

${ }^{10}$ Про схвалення Всеохоплюючої стратегії імплементації гл. IV («Санітарні та фітосанітарні заходи») p. IV «Торгівля і питання, пов’язані з торгівлею» Угоди про асоціацію між Україною, з однієї сторони, та Європейським Союзом, Європейським Співтовариством з атомної енергії і їхніми державами-членами, 3 іншої сторони : розпорядження Кабінету Міністрів України від 24 лютого 2016 р. № 228-p. URL: https://zakon.rada.gov.ua/laws/show/228-2016-\%D1\%80. 
тварин, ідентифікації та реєстрації тварин, побічних продуктів тваринного походження, кормових добавок та кормів, стандартів утримання та поводження із тваринами. Повноваження з імплементації гл. 4 розподілені між Кабінетом Міністрів України, Міністерством аграрної політики та продовольства України, Державною службою України 3 безпечності харчових продуктів та захисту споживачів, Міністерством охорони здоров'я України та, у деяких випадках, Міністерством екології та природних ресурсів України як відповідальними органами щодо виконання зобов'язань у цій сфері. Варто зазначити, що для скоординованої імплементації норм щодо санітарного та фітосанітарного контролю, захисту прав споживачів створений єдиний компетентний орган - Державна служба України з питань безпечності харчових продуктів та захисту споживачів, яка виконує функції колишніх Державної ветеринарної та фітосанітарної служби, Державної інспекції $з$ питань захисту прав споживачів та Державної санітарноепідеміологічної служби.

Аналіз Стратегії свідчить про те, що вона включає до плану імплементації практично весь комплекс базового (горизонтальне) та галузевого (вертикальне) «продовольчого законодавства» $\mathrm{EC}$, охоплює понад 200 відповідних нормативно-правових актів. Перелік цих актів вражає, починаючи 3 базового Регламенту № $178 / 2002^{11}$, що визначає поняття та принципи всього «продовольчого законодавства» $\mathrm{CC}$, Регламенту № 853/2004 ${ }^{12}$ про спеціальні гігієнічні правила для харчових продуктів тваринного походження та Регламенту № 854/2004 ${ }^{13}$ щодо норм офіційного контролю продуктів тваринного походження, призначених для споживання людьми, включаючи директиви щодо проблем здоров'я тварин i ветеринарних вимог, завершуючи рішеннями Комісії з розміщення на ринку окремих видів генетично модифікованих продуктів ${ }^{14,15,16}$. Стратегія визначає

\footnotetext{
${ }^{11}$ Regulation (EC) № 178/2002 of the European Parliament and of the Council of 28 January 2002 laying down the general principles and requirements of food law, establishing the European Food Safety Authority and laying down procedures in matters of food safety. URL: https://eur-lex.europa.eu/legalcontent/EN/TXT/?qid=1547720594534\&uri=CELEX:32002R0178.

${ }^{12}$ Regulation (EC) № 853/2004 of the European Parliament and of the Council of 29 April 2004 laying down specific hygiene rules for food of animal origin. URL: https://eur-lex.europa.eu/legalcontent/EN/TXT/?qid=1547720594534\&uri=CELEX:32002R0853.

${ }^{13}$ Regulation (EC) № 854/2004 of the European Parliament and of the Council of 29 April 2004 laying down specific rules for the organization of official controls on products of animal origin intended for human consumption. URL: https://eur-lex.europa.eu/legal-content/EN/TXT/?qid=1547720824996\&uri= CELEX:32004R0854.

${ }^{14}$ Regulation (EC) № 1829/2003 of the European Parliament and of the Council of 22 September 2003 on genetically modified food and feed (Text with EEA relevance). URL: https://eur-lex.europa.eu/legalcontent/EN/TXT/?qid= 1547725755778\&uri=CELEX:32003R1829.

15 Regulation (EC) № 1830/2003 of the European Parliament and of the Council of 22 September 2003 concerning the trace ability and label ling of genetically modified organisms and the trace ability of food and feed products produced from genetically modified organisms and a mending Directive 2001/18/EC. URL: https://eur-lex.europa.eu/legalcontent/EN/TXT/?qid=1547725663688\&uri=CELEX:32003R1830.

${ }^{16}$ Regulation (EC) № 1924/2006 of the European Parliament and of the Council of 20 December 2006 on nutrition and health claims made on foods. URL: https://eur-lex.europa.eu/legal-content/EN/TXT/ ?qid=1547725328792\&uri=CELEX:32006R1924.
} 
строк імплементації кожного заходу на період 2016-2021 pp. Оцінка переліку заходів, які охоплюють практично всі сфери громадського здоров'я, здоров'я тварин та фітосанітарних правил, дозволяє стверджувати, що поступовою реалізацією Стратегії започаткована реформа української нормативноправової бази, у результаті якої, по суті, відбудеться поширення відповідних норм/положень СС на території України. Очевидно, що такі зміни, зумовлені необхідністю розвитку торговельних відносин України з СС, матимуть вагомі наслідки як для економіки i зовнішньої торгівлі, так i для інших сфер суспільного життя.

Адаптація до вимог якості i безпечності продукції, передбачених технічними бар'єрами в торгівлі і фітосанітарними заходами, є складним, тривалим i витратним процесом, відсутність впровадження якого перешкоджає виходу на європейські ринки більшості потенційних українських постачальників ${ }^{17}$.

Варто зазначити, що для того, щоби скористатися преференціями в межах вільної торгівлі між Україною та СС, товар має походити з України або з СС та відповідати правилам походження, визначеним у Протоколі I Угоди про асоціацію. Документом, який підтверджує походження товару із країни, якій надається преференційний режим у межах зони вільної торгівлі, є сертифікат EUR.1, а для товарів, вартість яких не перевищує 6 000 євро, - декларація-інвойс (ст. 22 Протоколу I до Угоди про асоціацію). 31 січня 2016 р. сертифікати походження (переміщення) товарів EUR.1 видають митні органи Державної фіскальної служби України на безоплатній основі виключно на товари походженням 3 України, відповідно до процедурних умов, затверджених наказом Міністерства фінансів України від 20 листопада 2017 р. № $950^{18}$.

Головним позитивним результатом створення зони вільної торгівлі між Україною та ЄС для збільшення експорту сільськогосподарської продукції $\epsilon$ введення тарифних квот із нульовою ставкою мита. Кожен суб'єкт зовнішньоекономічної діяльності України може скористатися наявними тарифними квотами на експорт сільськогосподарської продукції, інформацію про які (загальні обсяги та за кожним видом продукції) можна отримати на офіційному сайті Державної фіскальної служби України. Порядок контролю за розподілом тарифної квоти затверджено наказом Мінфіну від 11 грудня 2014 р. № 1203 (на жаль, на сьогоднішній день не

\footnotetext{
17 Зовнішньоекономічні відносини України 3 EC. URL: http://forumkyiv.org/uk/analytics/ zovnishnoekonomichni-vidnosini-ukrayini-z-yes.

18 Про затвердження Порядку заповнення та видачі митницею сертифіката 3 перевезення (походження) товару EUR.1 : наказ Міністерства фінансів України від 20 листопада 2017 р. № 950. URL: https://zakon.rada.gov.ua/laws/show/z1563-17.
} 
набув чинності) ${ }^{19}$. Зокрема, встановлення безмитних тарифних квот $\mathrm{CC}$ передбачено для 36 видів вітчизняних сільськогосподарських товарів (наприклад: для яловичини, свинини, баранини, м'яса птиці, молока, вершків, йогуртів, зернових, висівків, меду, цукру, крохмалю, грибів, часнику, солоду, виноградного і яблучного соків, вершкового масла, цигарок, етанолу, яєць та ін.). Водночас для свинини і м'яса птиці, грибів, яєць та альбумінів уведено додаткові тарифні квоти. У свою чергу, Україна встановила тарифні квоти для 3 видів товарів із СС (свинина і м'ясо птиці, напівфабрикати із м'яса птиці, цукор) та передбачила додаткові тарифні квоти для м'яса птиці та цукру.

Відповідно до норм Свропейського Союзу, розподіл (адміністрування) тарифних квот здійснюється за двома принципами:

- «Перший прийшов - перший обслуговується» - оформлення ввезення товару на митну територію ЄС у межах тарифної квоти відбувається залежно від наявності невикористаного залишку відповідної квоти на момент подачі супровідних документів. Крім того, першим оформлюється той товар, супровідні документи щодо якого надійшли першими. Митні органи країн-членів СС через Єврокомісію списують обсяги поставок із відповідної тарифної квоти. Поточну інформацію, що коригується ввечері кожного робочого дня, про залишки тарифних квот СС можна переглянути на офіційному порталі Європейської комісії в режимі онлайн;

- через систему «імпортного ліцензування» - видача ліцензій на ввезення в межах тарифних квот здійснюється за запитом імпортера країни-члена ЄС. Потенційні імпортери української сільськогосподарської продукції подають відповідну заявку на право здійснення імпорту (отримання ліцензії) до Генерального директорату Свропейської комісії «Аграрні питання та розвиток сільської місцевості». $€$ обмеження в часі, протягом якого можна зарезервувати відповідний обсяг квот ${ }^{20}$. Інформація про залишки тарифних квот, які видаються через систему імпортних ліцензій, надається в разі звернення компетентного органу з відповідним запитом на адресу директорату Комісії з питань сільського господарства. Для кожного типу товару, преференційне постачання якого здійснюватиметься з використанням імпортних ліцензій, «імплементаційні регламенти» містять певні часові та кількісні норми ${ }^{21}$.

\footnotetext{
19 Про затвердження Поряду контролю за розподілом тарифної квоти : наказ Міністерства фінансів України від 11 грудня 2014 р. № 1203. URL: http://zakon.rada.gov.ua/laws/show/z1655-14.

20 Угода про асоціацію між Україною, з однієї сторони, та Європейським Союзом, Європейським співтовариством з атомної енергії і їхніми державами-членами, з іншої сторони, від 27 червня 2014 р. URL: http://zakon2.rada.gov.ua/laws/show/984_011.

21 Офіційний сайт Міністерства економічного розвитку та торгівлі України. URL: http://www.me.gov.ua/?lang=uk-UA.
} 
Наприклад, ліцензування імпорту зернових відбувається на щотижневих засадах. Залежно від кількості заявок на отримання ліцензій на імпорт до $€ C$, поданих у період, визначений для кожної тарифної квоти, застосовується коефіцієнт розподілу квоти із зазначенням \% від заявленого 3 боку імпортера обсягу. У разі імпорту до СС м'ясної (яловичина, свинина, свійська птиця) та яєчної продукції ліцензування в межах відповідних річних квот розподіляється рівними частками щоквартально, по $25 \%$ від загального обсягу квоти. Детальні процедури ліцензування, у межах використання тарифних квот, закріплено для:

- зернових в Регламенті ЄС № 2015/208122;

- свинини в Регламенті № 2015/2076 23 ;

- м'яса птиці в Регламенті 2015/207824;

- яловичини в Регламенті № 2015/207925.

Експортери, які не встигли скористатися можливостями вищезазначених принципів, можуть експортувати сільськогосподарську продукцію понад визначений обсяг за загальним режимом, тобто за умовами оподаткування (ставки мита), які діяли для України до запровадження зони вільної торгівлі. Також Угодою про асоціацію передбачене поступове збільшення обсягів квот для України на постачання до Європейського Союзу сільськогосподарської продукції. Водночас положеннями Угоди про асоціацію розгляд питання щодо прискорення та розширення умов лібералізації між Україною та ЄС буде можливий через 5 років із дати застосування торговельних положень Угоди, тобто не раніше $2021 \mathrm{p}$.

Отже, можемо дійти висновку, що ухвалення Угоди про асоціацію зумовило зміни та позитивно вплинуло на національне нормативноправове регулювання сільськогосподарського виробництва і ринку в Україні. Країни СС - це перспективний ринок збуту для української сільськогосподарської продукції, адже його платоспроможність значно вища, ніж інших доступних для України світових ринків, також позитивною стороною $є$ помірні витрати на логістику в разі постачання до

\footnotetext{
${ }^{22}$ Commission Implementing Regulation (EU) 2015/2081 of 18 November 2015 opening and providing for the administration of import tariff quotas for certain cereals originating in Ukraine. URL: https://eurlex.europa.eu/legal-content/EN/ALL/?uri=CELEX:32015R2081.

${ }^{23}$ Commission Implementing Regulation (EU) № 2015/2076 of 18 November 2015 opening and providing for the administration of Union import tariff quotas for fresh and frozen pig meat originating in Ukraine. URL: https://eur-lex.europa.eu/legal-content/EN/TXT/?qid=1547721586082\&uri=CELEX:32015R2076.

${ }^{24}$ Commission Implementing Regulation (EU) № 2015/2390 of 17 December 2015 establishing the al location coefficient to be applied to the quantities covered by the applications for import rights lodged from 1 to 7 December 2015 under the tariff quotas opened by Implementing Regulation (EU) 2015/2078 for poultry meat originating in Ukraine. URL: https://eur-lex.europa.eu/legal-content/EN/TXT/?qid=1547721648605\&uri= CELEX:32015R2390.

${ }^{25}$ Commission Implementing Regulation (EU) № 2015/2079 of 18 November 2015 opening and providing for the administration of a Union import tariff quota for fresh and frozen beef and veal originating in Ukraine. URL: https://eur-lex.europa.eu/legal-content/EN/TXT/?qid=1547721648605\&uri=CELEX:32015R2379.
} 
країн ЄС. Найбільш вагомі позитивні зміни стосуються саме вимог щодо підвищення якості сільськогосподарської продукції завдяки створенню ефективного інституційного забезпечення контролю якості, нормативного закріплення вимог до санітарних умов виробництва, технічного забезпечення виробництва, кормів тварин, сертифікації і стандартизації тощо. Варто зазначити, що такі зміни не лише сприяють активізації зовнішньої торгівлі з $\mathrm{CC}$, а й забезпечують захист прав споживачів на території України, покращують «імідж» української продукції в усьому світі, сприяють економічному розвитку країни шляхом запровадження новітніх технологій на виробництві, підвищення кваліфікації працівників у галузях сільського господарства та переробної (харчової) промисловості.

\section{2. Особливості національного організаційно-правового регулювання у сфері виробництва та розподілу продукції сільського господарства в СС та Україні}

Міжнародно-правове регулювання у сфері виробництва та розподілу продукції сільського господарства в Європейському Союзі здійснюється шляхом реалізації Спільної аграрної політики СС (далі - САП). Роль САП полягає у створенні умов, які мають підтримувати та заохочувати сільськогосподарських виробників, ураховуючи довгострокові завдання: життєздатного виробництва продовольства, сталого управління природними ресурсами i пом'якшення наслідків зміни клімату, збалансованого територіального розвитку. 2013 р. САП ЄС зазнала змін (на період 2014-2020 pp., порівняно iз 2007-2013 рp.), проте iï цілі залишилися незмінними: модернізація сільського господарства, стабільне функціонування ринку сільськогосподарської продукції, забезпечення доходів працівників, зайнятих у галузі, що буде не нижчим прийнятих стандартів життя.

Завдяки системним зусиллям держав $Є С$ європейська модель сільського господарства базується на трьох чинниках: фермерському господарстві сімейного типу, багатофункціональній ролі галузі в національних економіках, захисті доходів товаровиробників від ринкової і природної стихій ${ }^{26}$.

Стратегія «Європа 2020» визначає три чинники зміцнення і розвитку економіки ${ }^{27}$ :

- розумне зростання, що базується на знаннях і інноваціях;

- сталий розвиток - базується на цілеспрямованому використанні ресурсів, екології і конкуренції;

- усеосяжне зростання - сприяння підвищенню рівня зайнятості населення, досягнення соціальної і територіальної згоди.

\footnotetext{
${ }^{26}$ The Common Agricultural Policy after 2013. URL: http://ec.europa.eu/agriculture/cap-post-2013/.

${ }^{27}$ Bernstein J., Cochrane N., Hasha G. The European Union's Common Agricultural Policy: Pressures for Change. United State Department of Agriculture. International agriculture and trade reports. WRS-99-2. October 1999. 56 p.
} 
Крім того, в аграрній політиці ЄС визначено 10 ключових засад цільового розподілу грошових субсидій для забезпечення $\mathrm{CA \Pi}^{28}$ i скорочення частки САП у бюджеті СС із $39 \%$ у 2013 р. до $33 \%$ у 2020 p. $^{29}$ На 2014-2020 pр. передбачено збільшити фінансування заходів, які б стимулювали споживання, зокрема, програми безоплатного чи пільгового розподілу молока, фруктів і овочів у школах. Деякі цільові заходи за цим напрямом тепер будуть фінансуватися 3 бюджету II фінансового блока САП та інших фондів $\epsilon^{30}$. Стимулювання екологізації сільського господарства в межах САП СС забезпечуватиметься за допомогою схеми екологічно сприятливих платежів, так званих «зелених» платежів. На диверсифікацію культур (вирощування не менше трьох), утримання постійних пасовищ, формування екологічних зон із консервацією $5 \%$, згодом $-7 \%$, землі, збереження біорозмаїття й елементів ландшафту) спрямовуватиметься 30\% національного річного бюджету. Субсидії на ці цілі встановлюються пропорційно площі сільгоспугідь без фіксації верхньої межі виплат фермеру ${ }^{31}$.

Узагалі, для реалізації пріоритетів САП передбачено 20 основних заходів, як-от: підтримка сільського господарства, «що базується на знаннях»; додаткова підтримка ферм, що отримують сертифікат якості продукції; підтримка «організованого сільгоспвиробництва» із кращою ринковою позицією (організацій продуцентів, «коротких» збутових ланцюгів тощо). Передбачена підтримка несільськогосподарської економічної диверсифікації в аграрних регіонах, розвитку органічного сільського господарства, створюваних фермерами спільних страхових фондів тощо ${ }^{32}$.

Що стосується розподілу сільськогосподарської продукції, то насамперед варто зазначити, що в Свропейському Союзі зовнішньоекономічні операції (міжнародні торговельні) здійснюються лише із третіми країнами, адже всередині СС не існує кордонів. Згідно зі ст. 26

\footnotetext{
${ }^{28}$ Основні пріоритети Спільної аграрної політики (САП) країн СC / Інститут аграрних ринків. URL: http://www.amdi.org.ua/home/amdi-news/21-news/300-the-main-priorities-of-the-common-agricultural-policycap-of-the-eu.html.

${ }^{29}$ Bernstein J., Cochrane N., Hasha G. The European Union's Common Agricultural Policy: Pressures for Change. United State Department of Agriculture. International agriculture and trade reports. WRS-99-2. October 1999. $56 \mathrm{p}$.

${ }^{30}$ Основні пріоритети Спільної аграрної політики (САП) країн $\mathrm{CC} /$ Інститут аграрних ринків. URL: http://www.amdi.org.ua/home/amdi-news/21-news/300-the-main-priorities-of-the-common-agricultural-policycap-of-the-eu.html.

${ }^{31}$ Bernstein J., Cochrane N., Hasha G. The European Union's Common Agricultural Policy: Pressures for Change. United State Department of Agriculture. International agriculture and trade reports. WRS-99-2. October 1999. $56 \mathrm{p}$.

32 Основні пріоритети Спільної аграрної політики (САП) країн $\mathrm{CC} /$ Інститут аграрних ринків. URL: http://www.amdi.org.ua/home/amdi-news/21-news/300-the-main-priorities-of-the-common-agricultural-policycap-of-the-eu.html.
} 
ДФСС, внутрішній ринок охоплює простір без внутрішніх кордонів, де забезпечено вільний рух товарів, осіб, послуг та капіталів ${ }^{33}$.

Правовий режим, який застосовується до товарів, які імпортуються в $\mathrm{CC}$ із третіх країн, залежить від таких обставин: 1) країна імпорту товару; 2) наявність чи відсутність двосторонніх угод між $С С$ та третьою країною (зокрема, для визначення режиму імпорту текстильних товарів); 3) категорія товару, який імпортується (текстильні/нетекстильні товари тощо). Однією 3 головних умов експортних поставок сільськогосподарської продукції до країн $\mathrm{CC} є$ забезпечення експортером безпеки продукції та контролю ії̈ з боку компетентних державних органів відповідно до вимог директив ЄС і Кодексу Аліментаріус.

Одним із перших кроків для експорту сільськогосподарської продукціїдо країн $\mathrm{CC} €$ включення держави до переліку країн, 3 яких членам Європейського Союзу дозволено здійснювати імпорт - із третіх країн (нечленів СС). Щоби країна була включена до цього переліку, їй необхідно дотримуватися вимог європейського законодавства щодо нагляду (моніторингу) за вмістом шкідливих речовин та їхніх залишків у продуктах, які призначені для експорту. Зазначимо, що ЄС має на місцях органи регулювання i нагляду (а також засоби моніторингу) за застосуванням широкого діапазону ветеринарних медикаментів та інших речовин у всіх класах тварин і продуктів тваринного походження, призначених для споживання людиною. Нормативно закріплені заходи, обов'язкові для дотримання експортерами й імпортерами під час увезення продуктів тваринного походження до країн $С С$, вимоги 3 моніторингу деяких речовин та їхніх залишків у живих тваринах та продуктах тваринного походження ${ }^{34}$.

Норми i правила (стандарти), які ухвалюються окремими підприємствами, пропонованими для затвердження (як постачальник), повинні відповідати або бути еквівалентні нормам і стандартам, визначеним законодавчими актам ЄС. Ці вимоги такі ж, як i ті, що висуваються до підприємств країн-членів СС. Передусім це стосується дотримання так званого «Пакета гігієни» - сукупності нормативних актів

\footnotetext{
33 Договір про Свропейський Союз від 7 лютого 1992 р., Маaстріхт. URL: https://zakon.rada.gov.ua/ laws/show/994_029.

${ }^{34}$ Regulation (EC) № 1925/2006 of the European Parliament and of the Council of 20 December 2006 on the addition of vitamins and minerals and of certain other substances to foods. URL: https://eur-lex.europa.eu/legalcontent/EN/TXT/?qid=1547725531481\&uri=CELEX:32006R1925; Regulation (EC) № 396/2005 of the European Parliament and of theCouncilof 23 February 2005 on maximum residue levels of pesticides in or on food and feed of plant and animal origin and a mending Council Directive 91/414/EECTextwith EEA relevance. URL: https://eurlex.europa.eu/legal-content/EN/TXT/?qid=1547724799762\&uri=CELEX:32005R0396; Commission Regulation (EC) № 136/2004 of 22 January 2004 laying down procedures for veterinary checks at Community border inspection posts on products imported from third countries (Text with EEA relevance). URL: https://eur-lex.europa.eu/legalcontent/EN/TXT/?qid=1547726018778\&uri=CELEX:32004R0136; Commission Regulation (EC) № 1881/2006 of 19 December 2006 setting maximum levels for certain contaminants in food stuffs (Text with EEA relevance). URL: https://eur-lex.europa.eu/legal-content/EN/TXT/?qid=1547724932699\&uri=CELEX:32006R1881.
} 
$€ C$, що визначають загальні гігієнічні вимоги до виробленої харчової продукції або продукції, що ввозиться до ЄС. Найважливішими документами, що входять до даного пакету, є регламенти Європейського Парламенту та Ради: № 852/2004 щодо гігієни харчових продуктів ${ }^{35}$; № 853/2004 щодо особливих правил гігієни для продуктів тваринного походження ${ }^{36}$; № 854/2004 щодо особливих правил організації офіційного контролю продуктів тваринного походження ${ }^{37}$; № 882/2004 щодо особливих правил перевірки дотримання законодавства про харчові продукти і корми для тварин, охорони здоров'я та добробуту тварин ${ }^{38}$. Зазначені регламенти розроблені для реалізації Регламенту № 178/2002 від 28 січня 2002 p. $^{39}$, який установлює загальні принципи і вимоги харчового законодавства, містить процедури, що стосуються безпеки харчових продуктів, охоплює практично всі питання безпеки харчової продукції, від виробництва до реалізації, також ним засновано Європейський орган із безпеки харчових продуктів.

Імпорт тварин і продуктів тваринного походження до країн СС повинен зазвичай супроводжуватися сертифікацією, відповідно до умов, які мають бути обов'язково дотримані, а також регламентований порядок видачі дозволів на ввезення і проведення перевірок. Особливості обов'язкової сертифікації викладені в конкретних актах СС. Так, наприклад, зразки сертифікатів для м'ясних продуктів, призначених для ввезення до $\mathrm{CC}$ iз третіх країн, визначені в рішенні ЄК № 2007/777 від 29 листопада 2007 р. про ветеринарно-санітарні і санітарно-гігієнічні умови і зразки сертифікатів імпорту м'ясної продукції, оброблених шлунків, міхурів i кишок, призначених для вживання в їжу, із третіх країн ${ }^{40}$. Усі виробники харчових,

${ }^{35}$ Regulation (EC) № 852/2004 of the European Parliament and of the Council of 29 April 2004 on the hygiene of food stuffs. URL: https://eur-lex.europa.eu/legal-content/EN/TXT/?qid=1547724235412\&uri= CELEX: 32004R0852.

${ }^{36}$ Regulation (EC) № 853/2004 of the European Parliament and of the Council of 29 April 2004 laying down specific hygiene rules for food of animal origin. URL: https://eur-lex.europa.eu/legal-content/EN/TXT/?qid= 1547720594534\&uri=CELEX:32002R0853.

${ }^{37}$ Regulation (EC) № 854/2004 of the European Parliament and of the Council of 29 April 2004 laying down specific rules for the organization of official controls on products of animal origin intended for human consumption. URL: https://eur-lex.europa.eu/legal-content/EN/TXT/?qid=1547720824996\&uri= CELEX:32004R0854.

${ }^{38}$ Regulation (EC) № 882/2004 of the European Parliament and of the Council of 29 April 2004 on official controls performed to ensure the verification of compliance with feed and food law, animal health and animal welfare rules. URL: https://eur-lex.europa.eu/legal-content/EN/TXT/?qid=1547724425700\&uri= CELEX:32004R0882.

${ }_{39}$ Regulation (EC) № 178/2002 of the European Parliament and of the Council of 28 January 2002 laying down the general principles and requirements of food law, establishing the European Food Safety Authority and laying down procedures in matters of food safety. URL: https://eur-lex.europa.eu/legalcontent/EN/TXT/?qid=1547720594534\&uri=CELEX:32002R0178.

${ }^{40}$ Commission Decision № 2007/777/EC of 29 November 2007 laying down the animal and public health conditions and model certificates for imports of certain meat products and treated stomachs, bladders and intestines for human consumption from third countries and repealing Decision 2005/432/EC (notified under document number C (2007) 5777) (Text with EEA relevance). URL: https://eur-lex.europa.eu/legalcontent/EN/TXT/?qid=1547724626834\&uri=CELEX:32007D0777. 
зокрема сільськогосподарських, продуктів повинні також дотримуватися мікробіологічних критеріїв, умов виробництва тощо.

Отже, можемо зазначити, що в нормативно-правових актах $\mathrm{CC}$ значну увагу приділено контролю якості та дотриманню санітарних вимог під час виробництва та реалізації/торгівлі (зокрема, щодо експорту/імпорту) сільськогосподарської продукції. Здійснювати експорт до країн СС можуть не всі держави світу, а лише ті країни, згода на експорт яким надана $€ \mathrm{C}$ i товари яких відповідають стандартам/вимогам $\mathrm{CC}$, що підтверджується документально.

Після укладення Угоди про асоціацію між Україною та $Є С$, яка має окремі положення як про торгівлю, так і про сільське господарство, Кабінет Міністрів України Угоди визначив необхідні заходи. Ці заходи передусім стосуються наближення українського законодавства до європейського, зокрема щодо зовнішньої торгівлі та сільськогосподарської продукції, а саме: формування системи ключових показників статистики сільського, лісового та рибного господарств; збереження природного середовища; транскордонні перевезення генетично модифікованих організмів; стимулювання розвитку сільськогосподарських виробників ${ }^{41}$.

Сьогодні Україна виконала значний обсяг заходів у сфері технічного регулювання, передбачених Угодою про асоціацію. Реалізація цих заходів дозволить підвищити конкурентоспроможність української продукції, поступово зменшити технічні бар'єри в торгівлі, а також сприятиме збільшенню експорту української промислової (переробленої) продукції. Зокрема, ухвалено Закон України «Про технічні регламенти і оцінку відповідності», що є одним із ключових євроінтеграційних проектів ${ }^{42}$, що фактично доповнює низку інших законодавчих актів, а саме законів України «Про стандартизацію» ${ }^{43}$, «Про метрологію та метрологічну діяльність» ${ }^{44}$, ухвалення яких усунуло технічні бар'єри й юридичні перешкоди в торгівлі промисловими товарами, сприятиме відкриттю для українських товарів ринку ЄС та інших розвинутих країн світу. Закон «Про

\footnotetext{
41 Про виконання Угоди про асоціацію між Україною, з однієї сторони, та Свропейським Союзом, Європейським співтовариством 3 атомної енергії і їхніми державами-членами, з іншої сторони : постанова Кабінету Міністрів України від 25 жотвня 2017 р. № 1106. URL: https://zakon.rada.gov.ua/laws/show/1106-2017\%D0\%BF\#n13; Про імплементацію Угоди про асоціацію між Україною, з однієї сторони, та Свропейським Союзом Свропейським співтовариством з атомної енергії і їхніми державами-членами, з іншої сторони» : розпорядження Кабінету Міністрів України від 17 вересня 2014 р. № 847-p (втратило чинність). URL: https://zakon.rada.gov.ua/laws/show/847-2014-\%D1\%80.

42 Про технічні регламенти та оцінку відповідності : Закон України від 15 січня 2015 р. № 124-VIII. URL: https://zakon.rada.gov.ua/laws/show/124-19.

П3 Про стандартизацію : Закон України від 5 червня 2014 p. № $1315-$ VII. URL: https://zakon.rada.gov.ua/laws/show/1315-18.

${ }^{44}$ Про метрологію та метрологічну діяльність : Закон України від 5 червня 2014 р. № 1314-VII. URL: https://zakon.rada.gov.ua/laws/show/1314-18.
} 
технічні регламенти і оцінку відповідності» створює правове поле та механізми для ухвалення директив $\mathrm{CC}$, що дозволить розпочати процес переходу на європейські стандарти, а узгодження технічних регламентів стимулюватиме безперешкодний обіг, зокрема сільськогосподарської продукції, між Україною та ЄС. Крім того, не можна забувати, що означені дії мають позитивно вплинути і на якість продукції на внутрішньому ринку України, тобто сприяти захисту національного товароспоживача.

Що стосується захисту національних товаровиробників, то нормативна база складається передусім із законів України «Про захист національного товаровиробника від демпінгового імпорту» ${ }^{45}$, «Про захист національного товаровиробника від субсидованого імпорту» 46 «Про застосування спеціальних заходів щодо імпорту в Україну» ${ }^{47}$, ухвалених під час приєднання України до СОТ (відповідно, Україна та СС, будучи членами COT, мають уніфікований інструментарій у даній сфері). Крім того, варто зазначити такі напрями загальної інкорпорації європейського досвіду в українське законодавство:

- внесення змін або ухвалення нової редакції Закону України «Про зовнішньоекономічну діяльність» ${ }^{48}$ для відображення сучасних тенденцій регулювання міжнародної торгівлі і доступу до світових ринків, а також охоплення (забезпечення відповідності) положень правової системи ЄС (acquis communautaire), зокрема щодо: спрощення формальностей i процедур; гармонізації відповідних норм і правил; виконання міжнародних зобов'язань, тощо;

- зміна нормативних актів/правил щодо нетарифних методів регулювання зовнішньої торгівлі, наприклад квотування/ліцензування експорту/імпорту, технічних бар'єрів тощо ${ }^{49}$.

Результатом виконання умов Угоди про асоціацію, серед іншого, стало ухвалення «Концепції Державної цільової програми розвитку аграрного сектора економіки на період до 2020 р.» (розпорядження Кабінету Міністрів України від 30 грудня 2015 р. № 1437-р) ${ }^{50}$. Крім того, напрямами

\footnotetext{
45 Про захист національного товаровиробника від демпінгового імпорту : Закон України від 22 грудня 1998 p. № 330-XIV. URL: https://zakon.rada.gov.ua/laws/show/330-14.

46 Про захист національного товаровиробника від субсидованого імпорту : Закон України від 22 грудня 1998 р. № 331-XIV. URL: https://zakon.rada.gov.ua/laws/show/331-14.

47 Про застосування спеціальних заходів щодо імпорту в Україну : Закон України від 22 грудня 1998 p. № 332-XIV. URL: https://zakon.rada.gov.ua/laws/show/332-14.

48 Про зовнішньоекономічну діяльність : Закон України від 16 квітня 1991 р. № 959-XII. URL: https://zakon.rada.gov.ua/laws/show/959-12.

49 Проблемні питання регулювання зовнішньоекономічної діяльності України : системний звіт Ради бізнес-омбудсмену, 2015. 26 с.

50 Про схвалення Концепції Державної цільової програми розвитку аграрного сектора економіки на період до 2021 р. : розпорядження Кабінету Міністрів України від 30 грудня 2015 р. № 1437-p. URL: http://zakon.rada.gov.ua/laws/show/1437-2015-\%D1\%80.
} 
на шляху узгодження законодавства України 3 європейським законодавством є такі:

1) використання напрацювань Офісу ефективного регулювання BARDO - Зелена книга «Регулювання ринку зерна», завдяки проаналізованій та зведеній в ній інформації держані органи влади мають точну карту щодо актуалізації регуляторних актів ринку зерна;

2) за розрахунками в системі GTAP (Global Trade Analysis Project), сучасним інструментом економічного аналізу, моделювання та прогнозування економічного розвитку країн, галузей i навіть окремих видів економічної діяльності є налагодження роботи в Україні власного Експортно-кредитного агентства. Що, згідно 3 положеннями Закону України «Про забезпечення масштабної експортної експансії українських виробників шляхом страхування, гарантування та здешевлення кредитування експорту» від 20 грудня 2016 р. № 1792-VIII ${ }^{51}$, сприятиме зростанню вітчизняного валового внутрішнього продукту;

3) варто вивчати досвід міжнародних організацій (наприклад, ФАО) i країн, які мають розвинуте сільське господарство, обрати i розробити/впровадити оптимальний механізми розвитку сільської місцевості;

4) одним із важливих кроків є демонополізація структур, які займаються, наприклад збутом зерна, та підтримка малого та середнього сільгоспвиробника, створивши регіональні центри швидкого реагування, де буде надаватися кваліфікована допомога. Водночас доцільно розробити документ 3 алгоритмом дій учасника сільськогосподарського ринку, починаючи від виробництва i завершуючи реалізацією на внутрішньому/зовнішньому ринках. Необхідно забезпечити належну механізацію аграрного сектора завдяки державним субсидіям, пільгам та дотаціям. Необхідно також ввести обов'язковість страхування врожаю. Доцільне запровадження цільової підтримки спеціальних заходів агроекологічного спрямування в процесі виробництва сільськогосподарської продукції: органічне сільське господарство; екстенсивне господарювання.

\section{ВИСНОВКИ}

На міжнародному (усесвітній i регіональний) рівні регулювання сільськогосподарської сфери здійснюється не лише 3 метою отримання прибутку різними країнами світу, а і для вирішення глобальних проблем,

\footnotetext{
51 Про забезпечення масштабної експортної експансії українських виробників шляхом страхування, гарантування та здешевлення кредитування експорту : Закон України від 20 грудня 2016 р. № 1792-VIII. URL: http://zakon.rada.gov.ua/laws/show/1792-19.
} 
як-от: голод, безробіття, гарантування продовольчої безпеки населення, а також збереження природних ресурсів, збереження i покращення екологічної ситуації. Означені аспекти/проблеми стосуються кожної держави та кожної людини, тому вся світова спільнота повинна будувати свою діяльність, зокрема внутрішню і зовнішню політику, інституційноправову базу щодо виробництва і реалізації сільськогосподарської продукції, так, щоби сприяти досягненню зазначених цілей.

Актуальним залишається питання подальшої гармонізації на регіональному двосторонньому рівні національного законодавства України iз правом СС у сфері сільського господарства. Звісно, нині в межах Угоди про асоціацію 2014 р. до національної нормативно-правової бази України вже імплементована значна частина положень права Європейського Союзу, але ще $\epsilon$ над чим працювати. Проведення комплексного дослідження міжнародно-правового та національного регулювання здійснення імпортних/експортних операцій із сільськогосподарською продукцією дозволяє систематизувати нормативно-правову базу, проаналізувати статистичні показники виробництва та збуту агротоварів, а також визначити місце України на відповідному міжнародному та регіональному ринку 3 метою розвитку i підвищення ефективності національного сільського господарства.

\section{АНОТАЦІЯ}

Сільське господарство є надзвичайно чутливим сектором глобальної торговельної системи. Сільськогосподарська продукція i продукція харчової промисловості мають відмінну від інших різновидів товарів природу, що пов'язано з особливостями виробничого процесу (зокрема, зберігання, транспортування тощо), постійним попитом на них тому, що вони забезпечують щоденні природні потреби людини. Також важливу роль відіграє агропромисловий комплекс в історичному розвитку, культурі й економіці багатьох суспільств/держав, що не може не відбитися на природі сільськогосподарських товарів і нормативно-правовому й інституційно-організаційному (міжнародний багатосторонній i двосторонній, а також національний) регулюванні/забезпеченні торгівлі ними. Проблема полягає в тому, що існує нерівномірний доступ до сільськогосподарської продукції взагалі та їі різних видів зокрема, на різні ринки, значна різниця потреб у даних товарах. Тому вони мають бути максимально лібералізовані, а також захищені, крім того, окремої уваги потребує гарантування їхньої безпеки, а також безпеки їх виробництва для 
життя і здоров'я населення і навколишнього середовища. Ця мета може бути досягнута лише сукупністю економічних та правових методів регулювання виробництва і торгівлі сільськогосподарською продукцією. Однак для їх застосування необхідно розуміти суть проблеми, що являє собою міжнародна торгівля сільськогосподарською продукцією, іiі регулювання на міжнародному (наприклад, у межах зони вільної торгівлі між Україною та СС) та національному рівнях (наприклад, в Україні). У результаті процесів регіональної економічної інтеграції, зокрема на основі Угоди про асоціацію 2014 р., для доступу і наявності національної сільськогосподарської продукції на іноземному ринку необхідне узгодження національних вимог щодо іiі якості, безпечності тощо 3 вимогами/нормами (ветеринарні, фітосанітарні, санітарно-гігієнічні, технічні й ін.) держав, на ринки яких вона постачається. Отже, будучи значною мірою аграрною державою, Україна має виконувати міжнародні зобов'язання (зокрема, Угоди про асоціацію 2014 р.) і гармонізувати національні нормативно-правової акти із правилами СС.

\section{ЛІТЕРАТУРА}

1. Договір про Європейський Союз від 7 лютого 1992 р., Маастріхт. URL: https://zakon.rada.gov.ua/laws/show/994_029.

2. Заблоцький А. Коментар керівника сектора BRDO «Сільське господарство». Протокол круглого столу «Украӥнський ринок зерна: ефективне регулювання для світового лідерства». Київ, 2017. С. 1-7.

3. Про забезпечення масштабної експортної експансії українських виробників шляхом страхування, гарантування та здешевлення кредитування експорту : Закон України від 20 грудня 2016 р. № 1792-VIII. URL: http://zakon.rada.gov.ua/laws/show/1792-19.

4. Про застосування спеціальних заходів щодо імпорту в Україну : Закон України від 22 грудня 1998 p. № 332-XIV. URL: https://zakon.rada.gov.ua/laws/show/332-14.

5. Про захист національного товаровиробника від демпінгового імпорту : Закон України від 22 грудня 1998 р. № 330-XIV. URL: https://zakon.rada.gov.ua/laws/show/330-14.

6. Про захист національного товаровиробника від субсидованого імпорту : Закон України від 22 грудня 1998 р. № 331-XIV. URL: https://zakon.rada.gov.ua/laws/show/331-14.

7. Про зовнішньоекономічну діяльність : Закон України від 16 квітня 1991 p. № 959-XII. URL: https://zakon.rada.gov.ua/laws/show/959-12. 
8. Про метрологію та метрологічну діяльність : Закон України від 5 червня 2014 р. № 1314-VII. URL: https://zakon.rada.gov.ua/laws/show/ 1314-18.

9. Про ратифікацію Угоди про асоціацію між Україною, 3 однієї сторони, та Європейським Союзом, Свропейським співтовариством 3 атомної енергії і їхніми державами-членами, з іншої сторони : Закон України від 16 вересня 2014 р. № 1678-VII. Відомості Верховної Ради України. 2014. № 40. Ст. 2021.

10. Про стандартизацію : Закон України від 5 червня 2014 p. № 1315-VII. URL: https://zakon.rada.gov.ua/laws/show/1315-18.

11. Про технічні регламенти та оцінку відповідності : Закон України від 15 січня 2015 р. № 124-VIII. URL: https://zakon.rada.gov.ua/laws/show/124-19.

12. Зовнішньоекономічні відносини України 3 GC. URL: http://forumkyiv.org/uk/analytics/zovnishnoekonomichni-vidnosini-ukrayiniz-yes.

13. Про затвердження Порядку заповнення та видачі митницею сертифіката з перевезення (походження) товару EUR.1 : наказ Міністерства фінансів України від 20 листопада 2017 p. № 950. URL: https://zakon.rada.gov.ua/laws/show/z1563-17.

14. Про затвердженняПоряду контролю за розподілом тарифної квоти : наказ Міністерства фінансівУкраїни від 11 грудня 2014 р. № 1203. URL: http://zakon.rada.gov.ua/laws/show/z1655-14.

15. Основні пріоритети Спільної аграрної політики (САП) країн $\mathrm{С} \mathrm{/}$ Інститут аграрних ринків. URL: http://www.amdi.org.ua/home/amdi-news/21news/300-the-main-priorities-of-the-common-agricultural-policy-cap-of-theeu.html.

16. Офіційний сайт Міністерства економічного розвитку та торгівлі України. URL: http://www.me.gov.ua/?lang=uk-UA.

17. Офіційний сайт Представництва України при Свропейському Союзі та Європейському Співтоваристві з атомної енергіï. URL: https://ukraineeu.mfa.gov.ua/ua/ukraine-eu/trade-and-economic/atm.

18. Про виконання Угоди про асоціацію між Україною, 3 однієї сторони, та Європейським Союзом, Свропейським співтовариством 3 атомної енергії і їхніми державами-членами, з іншої сторони : постанова Кабінету Міністрів України від 25 жовтня 2017 p. № 1106. URL: https://zakon.rada.gov.ua/laws/show/1106-2017-\%D0\%BF\#n13.

19. Проблемні питання регулювання зовнішньоекономічної діяльності України : системний звіт Ради бізнес-омбудсмену, 2015. 26 с. 
20. Про внесення змін до Рішення Ради СС № 2014/668/EU від 23 червня 2014 р. стосовно підписання та тимчасове застосування Угоди про асоціацію між Україною та СС і його державами-членами : рішення Ради EC від 29 вересня 2014 p. № 2014/691/EU. URL: http://eurlex.europa.eu/legal-content/EN/TXT/?uri=CELEX\%3A32014D0691.

21. Про імплементацію Угоди про асоціацію між Україною, з однієї сторони, та Європейським Союзом Європейським співтовариством 3 атомної енергії і їхніми державами-членами, 3 іншої сторони : розпорядження Кабінету Міністрів України від 17 вересня 2014 р. № 847-р (втратило чинність). URL: https://zakon.rada.gov.ua/laws/show/847-2014$\%$ D1\%80.

22. Про схвалення Всеохоплюючої стратегії імплементації гл. IV («Санітарні та фітосанітарні заходи») p. IV «Торгівля і питання, пов’язані 3 торгівлею» Угоди про асоціацію між Україною, з однієї сторони, та Свропейським Союзом, Свропейським Співтовариством з атомної енергії і їхніми державами-членами, 3 іншої сторони : розпорядження Кабінету Міністрів України від 24 лютого 2016 p. № 228-p. URL: https://zakon.rada.gov.ua/laws/show/228-2016-\%D1\%80.

23. Про схвалення Концепції Державної цільової програми розвитку аграрного сектора економіки на період до 2021 р. : розпорядження Кабінету Міністрів України від 30 грудня 2015 р. № 1437-p. URL: http://zakon.rada.gov.ua/laws/show/1437-2015-\%D1\%80.

24. Про схвалення Стратегії розвитку системи технічного регулювання на період до 2020 р. : розпорядження Кабінету Міністрів України від 19 серпня 2015 p. № 844-p. URL: http://zakon2.rada.gov.ua/laws/show/844-2015$\%$ D1\%80\#n7.

25. Угода про асоціацію між Україною, 3 однісї сторони, та Свропейським Союзом, Свропейським співтовариством з атомної енергії і їхніми державами-членами, з іншої сторони, від 27 червня 2014 р. URL: http://zakon2.rada.gov.ua/laws/show/984_011.

26. Bernstein J., Cochrane N., Hasha G. The European Union's Common Agricultural Policy: Pressures for Change. United State Department of Agriculture. International agriculture and trade reports. WRS-99-2. October 1999. $56 \mathrm{p}$.

27. Commission Decision № 2007/777/EC of 29 November 2007 laying down the animal and public health conditions and model certificates for imports of certain meat products and treated stomachs, bladders and intestines for human consumption from third countries and repealing Decision 2005/432/EC (notified 
under document number C (2007) 5777) (Text with EEA relevance). URL: https://eur-lex.europa.eu/legalcontent/EN/TXT/?qid=1547724626834\&uri=CELEX: 32007D0777.

28. Commission Implementing Regulation (EU) 2015/2081 of 18 November 2015 opening and providing for the administration of import tariff quotas for certain cereals originating in Ukraine. URL: https://eur-lex.europa.eu/legalcontent/EN/ALL/?uri=CELEX:32015R2081.

29. Commission Implementing Regulation (EU) № 2015/2076 of 18 November 2015 opening and providing for the administration of Union import tariff quotas for fresh and frozen pig meat originating in Ukraine. URL: https://eur-lex.europa.eu/legal-

content/EN/TXT/?qid=1547721586082\&uri=CELEX:32015R2076.

30. Commission Implementing Regulation (EU) № 2015/2079 of 18 November 2015 opening and providing for the administration of a Union import tariff quota for fresh and frozen beef and veal originating in Ukraine. URL: https://eur-lex.europa.eu/legalcontent/EN/TXT/?qid=1547721648605\&uri=CELEX:32015R2379.

31. Commission Implementing Regulation (EU) № 2015/2390 of 17 December 2015 establishing the al location coefficient to be applied to the quantities covered by the applications for import rights lodged from 1 to 7 December 2015 under the tariff quotas opened by Implementing Regulation (EU) $2015 / 2078$ for poultry meat originating in Ukraine. URL: https://eurlex.europa.eu/legalcontent/EN/TXT/?qid=1547721648605\&uri=CELEX:32015R2390.

32. Commission Regulation (EC) № 136/2004 of 22 January 2004 laying down procedures for veterinary checks at Community border inspection posts on products imported from third countries (Text with EEA relevance). URL: https://eur-lex.europa.eu/legalcontent/EN/TXT/?qid=1547726018778\&uri=CELEX:32004R0136.

33. Commission Regulation (EC) № 1881/2006 of 19 December 2006 setting maximum levels for certain contaminants in food stuffs (Text with EEA relevance). URL: https://eur-lex.europa.eu/legalcontent/EN/TXT/?qid= 1547724932699\&uri=CELEX:32006R 1881.

34. Regulation (EC) № 178/2002 of the European Parliament and of the Council of 28 January 2002 laying down the general principles and requirements of food law, establishing the European Food Safety Authority and laying down procedures in matters of food safety. URL: https://eur-lex.europa.eu/legalcontent/EN/TXT/?qid=1547720594534\&uri=CELEX:32002R0178. 
35. Regulation (EC) № 1829/2003 of the European Parliament and of the Council of 22 September 2003 on genetically modified food and feed (Text with EEA relevance). URL: https://eur-lex.europa.eu/legal-content/EN/TXT/?qid= 1547725755778\&uri=CELEX:32003R1829.

36. Regulation (EC) № 1830/2003 of the European Parliament and of the Council of 22 September 2003 concerning the trace ability and labeling of genetically modified organisms and the traceability of food and feed products produced from genetically modified organisms and a mending Directive 2001/18/EC. URL: https://eur-lex.europa.eu/legalcontent/EN/TXT/? qid=1547725663688\&uri=CELEX: 32003R1830.

37. Regulation (EC) № 1924/2006 of the European Parliament and of the Council of 20 December 2006 on nutrition and health claims made on foods. URL: https://eur-lex.europa.eu/legal-content/EN/TXT/?qid= 1547725328792\&uri= CELEX: 32006R1924.

38. Regulation (EC) № 1925/2006 of the European Parliament and of the Council of 20 December 2006 on the addition of vitamins and minerals and of certain other substances to foods. URL: https://eur-lex.europa.eu/legalcontent/EN/TXT/?qid=1547725531481\&uri=CELEX:32006R1925.

39. Regulation (EC) № 396/2005 of the European Parliament and of the Council of 23 February 2005 on maximum residue levels of pesticides in or on food and feed of plant and animal origin and a mending Council Directive 91/414/EEC. Text with EEA relevance. URL: https://eur-lex.europa.eu/legalcontent/EN/TXT/?qid=1547724799762\&uri=CELEX:32005R0396.

40. Regulation (EC) № 852/2004 of the European Parliament and of the Council of 29 April 2004 on the hygiene of food stuffs. URL: https://eurlex.europa.eu/legal-

content/EN/TXT/?qid=1547724235412\&uri=CELEX:32004R0852.

41. Regulation (EC) № 853/2004 of the European Parliament and of the Council of 29 April 2004 laying down specific hygiene rules for food of animal origin. URL: https://eur-lex.europa.eu/legalcontent/EN/TXT/?qid= 1547720594534\&uri=CELEX: 32002R0853.

42. Regulation (EC) № 854/2004 of the European Parliament and of the Council of 29 April 2004 laying down specific rules for the organization of official controls on products of animal origin intended for human consumption. URL: $\quad$ https://eur-lex.europa.eu/legal-content/EN/TXT/?qid=1547720824996 \&uri=CELEX: 32004R0854.

43. Regulation (EC) № 882/2004 of the European Parliament and of the Council of 29 April 2004 on official controls performed to ensure the 
verification of compliance with feed and food law, animal health and animal welfare rules. URL: https://eur-lex.europa.eu/legal-content/EN/TXT/?qid= 1547724425700\&uri=CELEX: 32004R0882.

44. The Common Agricultural Policy after 2013. URL: http://ec.europa.eu/agriculture/cap-post-2013/.

\section{Information about author:}

Holubieva V. O.,

Ph. D., Docent,

Professor, Department of International and European Law Kyiv National Economic University named after Vadym Hetman

54/1, Prospect Peremogy, Kyiv, 03057, Ukraine 